\title{
Risk factors for diseases of the cardiovascular system among Catholics living in areas of southern Poland
}

\section{Czynniki ryzyka wystapienia chorób układu sercowo-naczyniowego wśród katolików zamieszkujących tereny południowej Polski}

\author{
Anna Majda ${ }^{1}$, Joanna Zalewska-Puchała ${ }^{1}$, Alicja Kamińska ${ }^{1}$, Iwona Bodys-Cupak ${ }^{1}$, Marcin Suder ${ }^{2}$ \\ ${ }^{1}$ Faculty of Health Sciences, Jagiellonian University Medical College, Krakow, Poland \\ Head of the Faculty: Prof. Tomasz Brzostek MD, PhD \\ ${ }^{2}$ Department of Applications of Mathematics in Economics, Faculty of Management, AGH University, Krakow, Poland \\ Head of the Department: Prof. Henryk Gurgul PhD
}

Key words: risk factors, cardiovascular disease, religion.

Słowa kluczowe: czynniki ryzyka, choroby sercowo-naczyniowe, religia.

\begin{abstract}
Introduction: Cardiovascular diseases (CVD) are the most frequent cause of mortality of Polish residents. In Poland, there are few publications regarding research on the influence of people's religiosity on their health.

Aim of the research: To determine some factors of cardiovascular risk and the risk of cardiovascular events among Catholics. Material and methods: This cross-sectional study was conducted among 134 randomly selected Catholics and based on the results of: questionnaire survey, anthropometric measurements, physical examination, the SCORE scale, laboratory tests (CRP, homocysteine. glucose, total cholesterol, HDL, and triglycerides) and assessing the risk of cardiovascular events based on the SCORE scale. Statistical analysis was based on the $\chi^{2}$ test. Founded significance level was 0.05 .

Results: More than half of the respondents were diagnosed delevated homocysteine level and gluteal-femoral obesity. A little more than half of those surveyed had elevated total cholesterol levels and increased blood pressure, a little more than one-quarter of the respondents had raised triglyceride levels, and one-tenth had heightened glucose and C-reactive protein levels. The higher the age of the respondents, the more often the results of their biochemical exceed standards. Over half of those examined were diagnosed with overweight or obesity. Among examined gynoid obesity prevailed over android obesity. The risk assessment of CVD Catholics revealed that among the modifiable factors, biochemical levels of homocysteine proved to be the most important new risk factor, but among the classic factors it was blood pressure value. More than half of the respondents had moderate risk of cardiovascular events in the study group.

Conclusions: Nurses should promote pro-health attitudes, and should encourage the elimination of risk factors and biochemical testing and measurement among Catholics, who are a religious group at higher risk of cardiovascular disease.
\end{abstract}

\section{Streszczenie}

Wprowadzenie: Choroby układu sercowo-naczyniowego stanowią najczęstszą przyczynę zgonów w Polsce. Nie ma wielu publikacji dotyczących wyników badań nad wpływem religijności na zdrowie człowieka, chociaż wzrasta zainteresowanie tym tematem wśród praktyków zdrowia publicznego.

Cel pracy: Określenie wybranych czynników ryzyka sercowo-naczyniowego oraz ryzyka wystąpienia incydentu sercowo-naczyniowego u katolików.

Materiał i metody: Badania przekrojowe przeprowadzono u 134 katolików i oparto na wynikach kwestionariusza ankiety, pomiarów antropometrycznych, badania przedmiotowego i badań laboratoryjnych (białko C-reaktywne, homocysteina, stężenie glukozy, cholesterolu całkowitego, frakcji HDL cholesterolu i triglicerydów) oraz ocenie ryzyka wystąpienia incydentów sercowo-naczyniowych na podstawie skali SCORE. Analizę statystyczną przeprowadzono na podstawie testu $\chi^{2}$. Założony poziom istotności wynosił 0,05.

Wyniki: U ponad połowy badanych katolików zdiagnozowano zwiększone stężenie homocysteiny oraz otyłość pośladkowo-udową. U ponad połowy badanych stwierdzono także podwyższone stężenie cholesterolu całkowitego, u ponad 1/4 zwiększone stężenie triglicerydów, u 1/10 zwiększone stężenie glukozy, a u prawie 1/5 podwyższone stężenie białka C-reaktywnego. Z wiekiem badanych wyniki badań biochemicznych przekraczały coraz bardziej normy. U ponad połowy badanych zdiagnozowano nadwagę lub otyłość. Przeważała otyłość gynoidalna nad otyłością androidalną. Ocena zagrożenia chorobami układu sercowo-naczyniowego u katolików wykazała, że istotnym, nowym modyfikowalnym czynnikiem 
ryzyka jest stężenie homocysteiny, a klasycznym - stężenie cholesterolu całkowitego i triglicerydów. U ponad połowy badanych stwierdzono umiarkowane ryzyko wystąpienia incydentów sercowo-naczyniowych. Płeć i wiek badanych okazały się istotnymi, zmiennymi i niemodyfikowalnymi czynnikami ryzyka chorób układu krążenia.

Wnioski: Pielęgniarki powinny promować postawy prozdrowotne, zachęcać do eliminacji czynników ryzyka oraz do wykonywania badań biochemicznych i pomiarów u katolików, będących grupą religijną podwyższonego ryzyka wystąpienia chorób układu krążenia.

\section{Introduction}

There are not many publications concerning research on the effect of religiosity on human health in the Polish scientific literature, although interest in this subject among public health practitioners is growing. However, published data from many epidemiological studies carried out in the world suggest a positive link between religiosity and survival rate and the beneficial effect of religiosity on reducing the incidence of coronary artery (heart) disease, cancer, and mental illness [1-4].

The occurrence of, and mortality due to, diseases of the cardiovascular system are associated with the occurrence of risk factors for atherosclerosis. These can be divided into conventional modifiable risk factors and new modifiable risk factors, as well as nonmodifiable risk factors, which cannot be influenced, but which allow us to identify persons at high risk of developing cardiovascular disease (CVD) [5-10].

Diseases of the cardiovascular system are the most serious cause of death in Poland, and in most developed countries [11]. Research on the frequency of occurrence of CVD risk factors in various social/ religious groups enables prediction of disease risk and optimisation of preventative actions.

\section{Aim of the research}

The aim of the research was to attempt to determine (define) among Catholics:

a) selected modifiable cardiovascular risk factors:

- classical ones: dyslipidaemias, blood pressure, blood glucose level, obesity,

- new ones: homocysteine concentration, C-reactive protein (CRP);

b) the risk of a fatal cardiovascular incident.

\section{Material and methods}

This study encompassed anthropometric measurements, physical examination, and laboratory tests (C-reactive protein (CRP), homocysteine, glucose, total cholesterol, high-density lipoprotein (HDL), and triglycerides), as well as an assessment of the risk of occurrence of cardiovascular incidents on the basis of the SCORE scale. Moreover, selected information obtained from a questionnaire survey was used. The cross-sectional study was conducted under statutory project K/ZDS/004688, which received the consent of Komisja Bioetyczna (Bioethics Committee)
KBET/79/B/2014. The selection of the test group was targeted. Subjects were recruited from among Catholics living in southern Poland. The research was conducted in Bielsko-Biala and Cieszyn (Silesia), as well as Krakow (Małopolska Voivodeship). The criteria for inclusion in the study were: age 20-96 years, and practising the Catholic religion.

The questionnaire included, amongst other things, questions about socio-demographic data, comorbidities, and medications taken by the studied persons. Anthropometric measurements encompassed body mass and height, as well as waist and hip circumference. Body mass index (BMI) as well as waist-to-hip ratio (WHR) was calculated for each person. Overweight was defined as a BMI of $25-29.9 \mathrm{~kg} / \mathrm{m}^{2}$, and obesity as $\mathrm{BMI} \geq 30 \mathrm{~kg} / \mathrm{m}^{2}$. Visceral (abdominal, android - appletype) obesity was defined on the basis of waist circumference ( $>88 \mathrm{~cm}$ in women and $>102 \mathrm{~cm}$ in men), and WHR (a waist-to-hip circumference ratio $>0.9$ in men and $>0.8$ in women indicating abdominal obesity). The above norms are consistent with European recommendations concerning prevention of cardiovascular diseases in clinical practice from 2012 [12].

Physical examinations encompassed measurement of blood pressure, which was measured three times at intervals of at least $2 \mathrm{~min}$. The first measurement was rejected; average values for systolic and diastolic blood pressure obtained from the second and third measurement were analysed. The division of patients according to blood pressure values was based on criteria in accordance with European recommendations concerning prevention of cardiovascular diseases in clinical practice [12]: optimum pressure $<120 / 80 \mathrm{~mm} \mathrm{Hg}$; normal 120-129/80-84 mm Hg; high normal 130-139/ 85-89 mm Hg; above normal blood pressures: arterial hypertension $\geq 140 / 90 \mathrm{~mm} \mathrm{Hg}$ : stage (grade) 1 hypertension 140-159/90-99 mm Hg; stage (grade) 2 hypertension 160-179/100-109 mm Hg; stage (grade) 3 hypertension $\geq 180 / \geq 110 \mathrm{~mm} \mathrm{Hg}$; isolated systolic hypertension $\geq 140 /<90 \mathrm{~mm} \mathrm{Hg}$.

Laboratory tests encompassed determination of the concentration of: CRP - by the immunoturbidimetric method, glucose - hexokinase method, homocysteine - enzymatic method, triglycerides - enzymatic-colorimetric method (GPO-PAP), total cholesterol - immunoenzymatic method, HDL - ASD direct method. Three test tubes in the Vacutainer system by Beckton Dickinson were used for the following determinations: glucose - plasma fluoride; homocysteine - plasma EDTA/serum; and lipid profile 
- serum; CRP - serum. All subjects were fasting. Normal ranges of values according to Diagnostyka laboratory: glucose $70-115 \mathrm{mg} / \mathrm{dl}$; lipid profile: total cholesterol 0-200 mg/dl, HDL cholesterol 30-75 mg/dl, triglycerides $0-150 \mathrm{mg} / \mathrm{dl}$; CRP $0-5 \mathrm{mg} / \mathrm{l}$; and homocysteine $0-12 \mu \mathrm{mol} / \mathrm{l}$.

On the SCORE scale, four categories of cardiovascular risk were distinguished: low (below 1\%), moderate $(\geq 1 \%$ to $<5 \%$ ), high $(\geq 5 \%$ to $<10 \%)$, and very high $(\geq 10 \%)[13]$.

\section{Statistical analysis}

Statistical analysis was performed using Microsoft Office Excel 2013 and Statgraphics Centurion software. Verification of the posited hypotheses about the relationship or lack thereof between particular features was performed using the chi-squared $\left(\chi^{2}\right)$ test of independence. A level of significance of 0.05 was assumed.

\section{Results}

\section{Characteristics of the studied group}

In total, 134 Catholics living in southern Poland took part in the study. $78.36 \%$ of those surveyed lived in towns; the remainder were inhabitants of the countryside (villages). The majority of the studied persons were women (64.93\%). The subjects were aged 20 to 96 years, the average age being 47.66 years. For the purposes of data analysis, subjects were divided into three age groups: under 39 years old (35.82\%), 40-59 years old (37.31\%), and 60 years old and over $(26.87 \%)$. Most of the subjects had higher education (56.72\%), followed by secondary (24.63\%), vocational (13.43\%), and primary (basic) education (5.22\%). Amongst all the studied persons, $79.85 \%$ were working (employed), the most common form of employment being white-collar jobs (67.16\%). For the majority of respondents $(70.15 \%)$, their source of livelihood was their professional work, $22.39 \%$ of respondents were retired, $4.5 \%$ had a disability pension, while $3.0 \%$ of those surveyed lived off an allowance/benefits. All subjects declared that they were practising Catholics. The obtained data indicated that in the studied group, $47.8 \%$ of persons suffered from chronic diseases. Most respondents (60.94\%) stated that they had hypertension, and the next most common conditions were type 2 diabetes and atherosclerosis of the peripheral arteries (18.75\% each), and ischaemic heart disease $(17.19 \%)$. Furthermore, 9.4\% of respondents were diagnosed with kidney disease; $6.25 \%$ had had cancer in the past and currently autoimmunological diseases, and $3.12 \%$ were diagnosed with cerebrovascular diseases. Moreover, $29.69 \%$ of respondents mentioned other diseases, i.e. allergies, thyroid disease, asthma, epilepsy, gout, paroxysmal atrial fibrillation, coeliac disease, and venous insufficiency. Among the chronically ill, $42.54 \%$ took medication. More than half of the respondents (66.66\%) were taking antihypertensive drugs: $28.7 \%$ - lipid-lowering drugs and $21.5 \%$ - anticoagulants and antidiabetic medication. Moreover, $36.84 \%$ of respondents marked the answer "other", e.g. Euthyrox, Letrox, Alertec, Zyrtec, Milurit, and Colchicine. Among persons taking medications long-term, $96.49 \%$ took them regularly as prescribed by a medical doctor.

\section{Laboratory tests - lipid disorders, blood glucose disturbances, C-reactive protein, homocysteine}

Analysing the obtained results of laboratory tests, it was ascertained that half of the studied Catholics (50.75\%) had above normal total cholesterol concentration, and this more often concerned women (W) than men (M) (W 55.17\% vs. M 42.55\%). As many as $93.28 \%$ of respondents had normal levels of HDL ("good") cholesterol, and in $10.34 \%$ of respondents (only women) this concentration was above normal, which was a significant difference $\left(\chi^{2}=5.21 ; p=0.02\right)$ in relation to men, $100 \%$ of whom had normal concentrations. Analysis of the triglyceride concentrations in the studied group revealed that $26.12 \%$ of subjects had above normal values, with elevated results being more frequent in men (W $20.69 \%$ vs. M 36.17\%). This was a significant difference $\left(\chi^{2}=3.79 ; p=0.05\right)$. In $10.45 \%$ of the total sample, the result for fasting blood glucose was above normal. Men more frequently had elevated glucose concentration (W 8.05\% vs. M 14.89\%). $17.91 \%$ of all respondents in the studied group had elevated CRP. Elevated concentrations were more common in women (W 19.54\% vs. M 14.89\%). An elevated concentration of homocysteine was diagnosed in over half of respondents (60.45\%). Men had an elevated results significantly more frequently (M 78.72\% vs. W 50.57) $\left(\chi^{2}=10.11 ; p=0.002\right)$ (Table 1$)$.

Analysis of results of laboratory tests in particular age groups (Table 2) showed:

- occurrence of above normal concentration of total cholesterol increased with age - up to the age of 59, and then above 60 years old, it dropped somewhat. Among respondents under the age of 39 years, it was significantly the lowest $\left(\chi^{2}=7.06 ; p=0.03\right)$,

- respondents under 39 and aged 40 to 59 years with HDL cholesterol above normal: $6.25 \%$ and $12.00 \%$, respectively,

- triglyceride levels above normal amongst subjects aged $40-59$ and over 60 years: $28.00 \%$ and $36.11 \%$, respectively,

- elevated glucose concentration most frequently occurred in respondents above 60 years (19.44\%),

- respondents aged 40 to 59 and over 60 years had elevated CRP concentration significantly more frequently $(14.00 \%$ and $38.89 \%)\left(\chi^{2}=15.74 ; p=0.0004\right)$, 
Table 1. Results of biochemical tests for the studied group of Catholics by gender

\begin{tabular}{|c|c|c|c|c|}
\hline Test results & Females (\%) & Males (\%) & Total (\%) & $\chi^{2}, p$ \\
\hline \multicolumn{5}{|l|}{ Total cholesterol: } \\
\hline Within normal range & 44.83 & 57.45 & 49.25 & \multirow[t]{2}{*}{$1.94,0.16$} \\
\hline Above normal & 55.17 & 42.55 & 50.75 & \\
\hline \multicolumn{5}{|l|}{ Cholesterol HDL: } \\
\hline Below normal & - & - & - & \multirow[t]{3}{*}{$5.21,0.02$} \\
\hline Within normal range & 89.66 & 100.00 & 93.28 & \\
\hline Above normal & 10.34 & 0.00 & 6.72 & \\
\hline \multicolumn{5}{|l|}{ Triglycerides: } \\
\hline Within normal range & 79.31 & 63.83 & 73.88 & \multirow[t]{2}{*}{$3.79,0.05$} \\
\hline Above normal & 20.69 & 36.17 & 26.12 & \\
\hline \multicolumn{5}{|l|}{ Glucose: } \\
\hline Below normal & - & - & - & \multirow[t]{3}{*}{$1.53,0.22$} \\
\hline Within normal range & 91.95 & 85.11 & 89.55 & \\
\hline Above normal & 8.05 & 14.89 & 10.45 & \\
\hline \multicolumn{5}{|l|}{ CRP: } \\
\hline Within normal range & 80.46 & 85.11 & 82.09 & \multirow[t]{2}{*}{$0.45,0.50$} \\
\hline Above normal & 19.54 & 14.89 & 17.91 & \\
\hline \multicolumn{5}{|l|}{ Homocysteine: } \\
\hline Within normal range & 49.43 & 21.28 & 39.55 & \multirow[t]{2}{*}{$10.11,0.002$} \\
\hline Above normal & 50.57 & 78.72 & 60.45 & \\
\hline
\end{tabular}

- respondents aged over 60 years had significantly the highest concentration of homocysteine $(83.33 \%)$ $\left(\chi^{2}=12.3 ; p=0.002\right)$.

Statistical analysis showed that level of education significantly affected the results of laboratory tests such as: total cholesterol $\left(\chi^{2}=12.03 ; p=0.007\right)$, triglycerides $\left(\chi^{2}=11.43 ; p=0.009\right)$, CRP $\left(\chi^{2}=9.33\right.$; $p=0.03)$, and homocysteine $\left(\chi^{2}=9.98 ; p=0.02\right)$. In persons with higher education, the results of these tests were normal. Also, working (being employed) significantly influenced the results of some laboratory tests, such as: glucose concentration $\left(\chi^{2}=9.25 ; p=\right.$ $0.009)$, triglycerides $\left(\chi^{2}=10.09 ; p=0.006\right)$, and homocysteine $\left(\chi^{2}=8.27 ; p=0.02\right)$. Results for white-collar workers were normal significantly more frequently than for blue-collar workers and the unemployed. Place of residence only significantly affected homocysteine concentration $\left(\chi^{2}=3.78 ; p=0.05\right)$ : persons living in rural areas had normal homocysteine concentration significantly more frequently.

\section{Physical examination}

Analysis of the obtained data showed that in the studied group, 32.09\% of subjects had normal blood pressure, $26.87 \%$ - optimal, and $21.64 \%$ - high normal. However, $19.41 \%$ of respondents had above normal pressure, significantly more frequently in the case of males (M 31.92\% vs. W 12.65\%) $\left(\chi^{2}=13.89 ; p=0.02\right)$ (Table 3). Above normal pressure was also most frequent amongst people aged $40-59$ years (22\%) (Table 4$)$. White-collar workers had normal blood pressure significantly more frequently $\left(\chi^{2}=20.09 ; p=0.03\right)$.

\section{Anthropometric measurements}

Body mass index in just under half of the respondents (41.79\%) was normal, while $34.33 \%$ of respondents were overweight, $21.64 \%$ of respondents were obese, and $2.24 \%$ were underweight. Overweight (M 40.43\% vs. W 31.03\%) and obesity (M 27.67\% vs. W $18.39 \%$ ) were more frequent among men than women. Waist-to-hip ratio in the studied group indicated a predominance of gluteal-femoral obesity (53.73\%) over abdominal obesity (46.27\%), with android (abdominal) obesity predominant in women (54.02\%), and gynoid (gluteal-femoral, pear-type) obesity predominant among men (68.09\%); this was a significant difference $\left(\chi^{2}=5.99 ; p=0.01\right)$ (Table 5). Amongst white-collar workers, gynoid obesity occurred significantly more 
Table 2. Results of biochemical tests for the studied group of Catholics by age

\begin{tabular}{|c|c|c|c|c|c|}
\hline Test results & $\begin{array}{c}\text { Under } 39 \text { years } \\
\text { old (\%) }\end{array}$ & $\begin{array}{l}\text { 40-59 years } \\
\text { old (\%) }\end{array}$ & $\begin{array}{l}\text { Over } 60 \text { years } \\
\text { old (\%) }\end{array}$ & Total (\%) & $\chi^{2}, p$ \\
\hline \multicolumn{6}{|l|}{ Total cholesterol: } \\
\hline Within normal range & 64.58 & 40.00 & 41.67 & 49.25 & \multirow[t]{2}{*}{$7.06,0.03$} \\
\hline Above normal & 35.42 & 60.00 & 58.33 & 50.75 & \\
\hline \multicolumn{6}{|l|}{ HDL cholesterol: } \\
\hline Within normal range & 93.75 & 88.00 & 100.00 & 93.28 & \multirow[t]{2}{*}{$4.84,0.09$} \\
\hline Above normal & 6.25 & 12.00 & 0.00 & 6.72 & \\
\hline \multicolumn{6}{|l|}{ Triglycerides: } \\
\hline Within normal range & 83.33 & 72.00 & 63.89 & 73.88 & \multirow[t]{2}{*}{$4.18,0.12$} \\
\hline Above normal & 16.67 & 28.00 & 36.11 & 26.12 & \\
\hline \multicolumn{6}{|l|}{ Glucose: } \\
\hline Within normal range & 95.83 & 90.00 & 80.56 & 89.55 & \multirow[t]{2}{*}{$5.15,0.08$} \\
\hline Above normal & 4.17 & 10.00 & 19.44 & 10.45 & \\
\hline \multicolumn{6}{|l|}{ CRP: } \\
\hline Within normal range & 93.75 & 86.00 & 61.11 & 82.09 & \multirow[t]{2}{*}{$15.74,0.0004$} \\
\hline Above normal & 6.25 & 14.00 & 38.89 & 17.91 & \\
\hline \multicolumn{6}{|l|}{ Homocysteine: } \\
\hline Within normal range & 54.17 & 42.00 & 16.67 & 39.55 & \multirow[t]{2}{*}{$12.3,0.002$} \\
\hline Above normal & 45.83 & 58.00 & 83.33 & 60.45 & \\
\hline
\end{tabular}

Table 3. The results of measurements of blood pressure in the studied group of Catholics by gender

\begin{tabular}{|lcccc|}
\hline Blood pressure & Women $(\%)$ & Men $(\%)$ & Total (\%) & $\chi^{2}, p$ \\
\hline Optimum & 32.18 & 17.02 & 26.87 & $13.89,0.02$ \\
Normal & 36.78 & 24.40 & 32.09 & \\
\hline High normal & 18.39 & 27.66 & 21.64 & \\
\hline Above normal & 12.65 & 31.92 & 19.41 & \\
\hline
\end{tabular}

Table 4. Results of measurements of blood pressure in the studied group of Catholics by age

\begin{tabular}{|lccccc|}
\hline Blood pressure & Up to $\mathbf{3 9}$ years old (\%) & $\mathbf{4 0 - 5 9}$ years old (\%) & Over $\mathbf{6 0}$ years old (\%) & Total (\%) & $\chi^{2}, p$ \\
Optimum & 37.50 & 24.16 & 16.67 & 26.87 & $10.612,0.389$ \\
Normal & 22.92 & 34.00 & 41.67 & 32.09 & \\
High normal & 22.92 & 20.00 & 22.22 & 21.64 \\
Above normal & 16.66 & 22.00 & 19.44 & 19.41 \\
\hline
\end{tabular}

Table 5. Results of measurements of WHR in the studied group of Catholics by gender

\begin{tabular}{|lcccc|}
\hline WHR & Women (\%) & Men (\%) & Total (\%) & $\chi^{2}, p$ \\
Abdominal obesity & 54.02 & 31.91 & 46.27 & $5.99,0.01$ \\
\hline Gluteal-femoral obesity & 45.98 & 68.09 & 53.73 & \\
\hline
\end{tabular}


frequently than among the unemployed - android obesity dominated amongst the latter $\left(\chi^{2}=9.22 ; p=0.009\right)$. Visceral (abdominal) obesity, when defined on the basis of waist circumference $>88 \mathrm{~cm}$ in women and $>102 \mathrm{~cm}$ in men, occurred in $36.57 \%$ of respondents (W $40.23 \%$; M 29.98\%). Thus the results obtained on the basis of waist circumference measurements (alone) were lower than the results obtained on the basis of WHR.

\section{The risk of cardiovascular events in Catholics}

Analysis of data evaluated on the SCORE scale allowed us to state that the surveyed Catholics most frequently had a moderate $(52.2 \%)$ risk of occurrence of cardiovascular events. Low risk was ascertained in $20.9 \%$, high in $15.7 \%$, and very high in $11.2 \%$ of respondents (Figure 1).

\section{Discussion}

We did not find any results of studies on the prevalence of risk factors among Catholics in the Polish literature. So we decided to compare our own results with the results of a 2002 cross-sectional nationwide survey: NATPOL PLUS (Nadciśnienie Tętnicze w Polsce Plus Zaburzenia Lipidowe i Cukrzyca (Hypertension in Poland Plus Lipid Disorders and Diabetes)), which concerned the prevalence of these factors in a representative sample of adult Poles, in which the most important cardiovascular risk factors turned out to be lipid disorders and hypertension [11]. Bearing in mind that Polish society is homogenous in terms of religion (a CBOS survey in November 2011 showed that 95\% of inhabitants of Poland declare themselves to be Catholics), it can be supposed that a significant proportion of those studied in NATPOL PLUS were Catholics.

The age of respondents in the present study (2096 years) was similar to that of the subjects in the NATPOL PLUS study (18-90 years). $26.87 \%$ of the studied Catholics had optimal blood pressure, which is somewhat more than in the NATPOL PLUS study (20\%); $21.64 \%$ of Catholics had high normal blood pressure (in the NATPOL PLUS study: 30\%); 19.41\% of Catholics had above normal blood pressure. In our study, persons declaring that they took antihypertensive drugs were not excluded. At the same time, a difference was noted between the percentage of Catholics declaring that they had hypertension (60.94\%) and the percentage of Catholics having blood pressure above the accepted norm at the time of having their blood pressure measured (19.41\%). However this may attest to taking medication regularly and effective treatment. In the NATPOL PLUS study, hypertension was ascertained in $29 \%$ of respondents; however, in our own study, $60.94 \%$ of respondents declared that they had hypertension. The studied Catholics declared that they most frequently took antihypertensive drugs $(66.66 \%)$, which is somewhat more frequently than respondents in NATPOL PLUS (62\%).

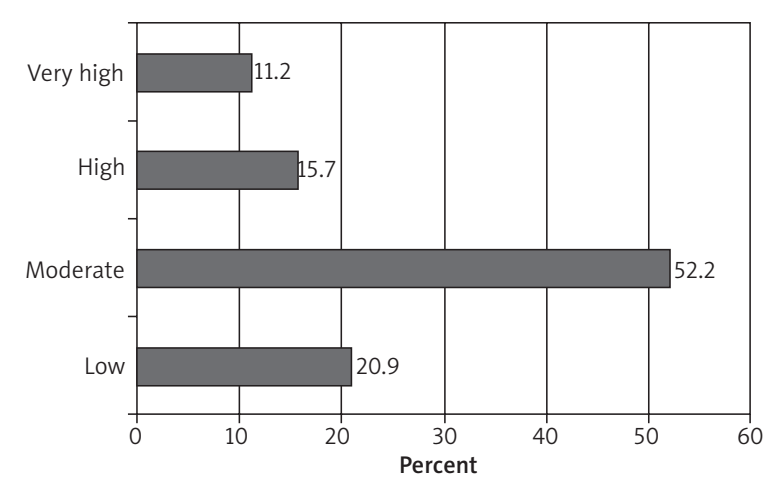

Figure 1 . The risk of cardiovascular events among the studied Catholics

Total cholesterol in the NATPOL PLUS study was above normal in $60.7 \%$ of respondents, more frequently than among the studied Catholics (50.75\%). HDL Cholesterol in the NATPOL PLUS study was below normal in $16.5 \%$ of respondents, whilst in our study, there were no subjects with HDL concentration below normal: persons with normal HDL concentration predominated $-93.28 \%$. The percentage of people with hypertriglyceridaemia in the NATPOL PLUS study was $30.1 \%$, and was higher among men than women $(37.7 \%$ vs. $23.1 \%, p<0.001$ ), and was somewhat higher than in our study on Catholics (M 36.17\% vs. W 20.69\%). The prevalence of hyperhomocysteinaemia in the group of studied Catholics was $60.45 \%$; it was significantly higher among men (M 78.72\% vs. W 50.57\%; $\chi^{2}=10.11$, $p=0.0015)$, and by far the highest in the oldest age group. The result for hyperhomocysteinaemia among Catholics was considerably higher than in the NATPOL PLUS study (17\%). There was an elevated level of CRP in the group of studied Catholics in $17.91 \%$ of the total sample; it was more common among women (W 19.54\% vs. M 14.89\%) and in persons over 60 years of age; in the NATPOL PLUS study, the frequency of elevated concentration of hs-CRP was 23.4\% (W 25.0\% vs. M $21.4 \%$ ). In $10.45 \%$ of all studied Catholics, fasting blood glucose was above normal, especially in men and persons above 60 years of age (W 8.05\% vs. M 14.89\%). In our own study, we also included persons who declared that they had diabetes. In the NATPOL PLUS study, $1.5 \%$ of respondents had irregular fasting blood glucose, $5.6 \%$ had diabetes, and $0.6 \%$ had impaired glucose tolerance. Undoubtedly, adoption of different normal ranges and somewhat different methodologies, or criteria for inclusion in the respective studies, had an influence on the small differences in results of biochemical tests between the Catholic study subjects and the NATPOL PLUS subjects.

Among Catholics, $34.33 \%$ of respondents were overweight - similar to the percentage in the NATPOL PLUS study (33.6\%); $21.64 \%$ were obese (somewhat more than in the NATPOL PLUS study: 19.1\%). Analysing the obtained results in terms of sex differen- 
tiation, it was found that more male Catholics than female Catholics were overweight (40.43\% vs. 31.03\%) and obese $(27.67 \%$ vs. $18.39 \%)$. Similarly, in the NATPOL PLUS study, men were overweight more frequently, but obesity occurred equally frequently in women and in men. The waist circumference to hip circumference ratio (WHR) in the studied group of Catholics indicated a predominance of gluteal-femoral obesity (53.73\%) over abdominal obesity (46.27\%), with android (abdominal, visceral) obesity predominating in the group of women $(54.02 \%)$, and gynoid (gluteal-femoral, pear-type) obesity among men (68.09\%). In the NATPOL PLUS study, visceral obesity on the basis of waist circumference was ascertained in $35 \%$ of women and $19 \%$ of men $(p<0.001)$, and in our own study, it was demonstrated in $29.78 \%$ of women and in $40.22 \%$ of men.

It is worth noting that in the present study, Catholics with higher education had normal laboratory test results significantly more frequently (total cholesterol, triglycerides, CRP, homocysteine), whereas whitecollar workers characteristically more frequently had a normal concentration of glucose, triglycerides, and homocysteine, and normal blood pressure and gluteal-femoral obesity dominated among them.

It is difficult to compare the risk of cardiovascular incidents among Catholics, which was moderate, with the risk in the sample in the NATPOL PLUS study because different tools were used to determine these risks.

\section{Conclusions}

In assessing the risk of diseases of the cardiovascular system in Catholics, the most significant risk factors proved to be: among modifiable new biochemical: homocysteine concentration, among modifiable conventional: total cholesterol and triglycerides. In the studied group of Catholics: gynoid obesity prevailed over android obesity, in over half, there existed a moderate risk of occurrence of cardiovascular events, significant non-modifiable variables influencing the risk of CVD were sex and age of the respondents. Nurses should promote pro-health attitudes, encourage the elimination of risk factors and biochemical testing and measurement among Catholics, who are a religious group with higher risk of cardiovascular disease.

\section{Conflict of interest}

The authors declare no conflict of interest.

\section{References}

1. Pawlikowski J, Marczewski K. Religia a zdrowie - czy religia może sprzyjać trosce o zdrowie? Część 1. Wartość zdrowia w wielkich religiach świata. Kardiol Dypl 2008; 10: 96-103.

2. Pawlikowski J, Sak J, Marczewski K. Religia a zdrowie czy religia może sprzyjać trosce o zdrowie? Część 2. Religijność a zdrowie. Kardiol Dypl 2009; 1: 87-94.
3. Jędrychowski W, Tobiasz-Adamczyk B, Olma A, Gradziliewicz P. Survival rates among seventh-day adventists compared with the general population of Poland. Scand J Soc Med 1985; 13: 49-52.

4. Majda A, Zalewska-Puchała J, Bodys-Cupak I, Kamińska A, Suder M. Rozpowszechnienie czynników ryzyka chorób sercowo-naczyniowych wśród wyznawców Kościoła Adwentystów Dnia Siódmego zamieszkujących teren Polski Południowej. Probl Piel 2015; 23: 190-6.

5. Wieloośrodkowe ogólnopolskie badanie stanu zdrowia ludności - projekt WOBASZ. Kardiol Pol 2005; 63 (supl. 4): 601-85.

6. Yusuf S, Hawken S, Ounpuu S, Dans T, Avezum A, Lanas F, McQueen M, Budaj A, Pais P, Varigos J, Lisheng L; INTERHEART Study Investigators. Effect of potentially modifiable risk factors associated with myocardial infarction in 52 countries (the INTERHEART study): case-control study. Lancet 2004; 364: 937-82.

7. Modrzejewski W, Musiał WJ. Stare i nowe czynniki ryzyka sercowo-naczyniowego - jak zahamować epidemię miażdżycy? Część I. Klasyczne czynniki ryzyka. Forum Zaburzeń Metabolicznych 2010; 2: 106-114.

8. Fudala M, Brola W, Przybylski W, Czernicki J. Czy badanie poziomu homocysteiny i witaminy $B_{12}$ ma szanse zostać kluczem do rozpoznania i leczenia choroby Alzheimera. Studia Medyczne 2008; 10: 53-8.

9. Janion M. Profilaktyka pierwotna chorób układu krążenia. Studia Medyczne 2006; 3: 107-19.

10. Cybulska B, Kłosiewicz-Latoszek L, Szostak WB, Szostak-Węgierek D. Prewencja chorób sercowo-naczyniowych - postępy 2015. Med Prakt 2016; 6: 23-32.

11. Zdrojewski T, Bandosz P, Szpakowski P, Konarski R, Jakubowski Z, Manikowski A, Wołkiewicz E, Łysia-Szydłowska W, Bautembach S, Wyrzykowski B. Rozpowszechnienie głównych czynników ryzyka chorób układu sercowo-naczyniowego w Polsce. Wyniki badania NATPOL PLUS. Kardiol Pol 2004; 61 (supl. IV): S5-26.

12. Europejskie wytyczne dotyczące zapobiegania chorobom serca i naczyń w praktyce klinicznej na 2012 rok.

13. Cybulska B, Szostak WB, Kłosiewicz-Latoszek L. Zapobieganie chorobom układu krążenia. In: Interna Szczeklika. Podręcznik chorób wewnętrznych. Gajewski P (ed.). Medycyna Praktyczna, Krakow 2014; 149-59.

\section{Address for correspondence:}

\section{Anna Majda MD}

Faculty of Health Sciences

Jagiellonian University Medical College

ul. Michałowskiego 12, 31-126 Krakow, Poland

Phone: +48506267170

E-mail: majdanna@poczta.onet.pl 